\title{
"A model of consumer buying behavior in relation to eco-intelligent products in catering"
}

\begin{tabular}{|c|c|}
\hline \multirow{7}{*}{ AUTHORS } & Darya G. Legeza (D https://orcid.org/0000-0003-4545-0366 \\
\hline & $\mathbb{R}$ http://www.researcherid.com/rid/l-7016-2018 \\
\hline & Thomas A. Brunner (D https://orcid.org/0000-0002-6770-6548 \\
\hline & $\mathbb{R}$ http://www.researcherid.com/rid/P-4515-2018 \\
\hline & Yukilay K. Kerimova (D) https://orcid.org/0000-0002-0166-5173 \\
\hline & $\begin{array}{l}\text { Tatyana V. Kulish } \\
\text { R http://www.researcherid.com/rid/C-2294-2019 }\end{array}$ \\
\hline & Anastasia S. Konovalenko (D https://orcid.org/0000-0001-9061-5989 \\
\hline ARTICLE INFO & $\begin{array}{l}\text { Darya G. Legeza, Thomas A. Brunner, Yukilay K. Kerimova, Tatyana V. Kulish } \\
\text { and Anastasia S. Konovalenko (2019). A model of consumer buying behavior in } \\
\text { relation to eco-intelligent products in catering. Innovative Marketing, 15(1), 54- } \\
65 . \text { doi:10.21511/im.15(1).2019.05 }\end{array}$ \\
\hline DOI & http://dx.doi.org/10.21511/im.15(1).2019.05 \\
\hline RELEASED ON & Wednesday, 20 March 2019 \\
\hline RECEIVED ON & Friday, 08 February 2019 \\
\hline \multirow[t]{2}{*}{ ACCEPTED ON } & Sunday, 17 March 2019 \\
\hline & $(c)$ EY \\
\hline LICENSE & $\begin{array}{l}\text { This work is licensed under a Creative Commons Attribution } 4.0 \text { International } \\
\text { License }\end{array}$ \\
\hline JOURNAL & "Innovative Marketing " \\
\hline ISSN PRINT & $1814-2427$ \\
\hline ISSN ONLINE & $1816-6326$ \\
\hline PUBLISHER & LLC "Consulting Publishing Company "Business Perspectives" \\
\hline FOUNDER & LLC "Consulting Publishing Company "Business Perspectives" \\
\hline
\end{tabular}

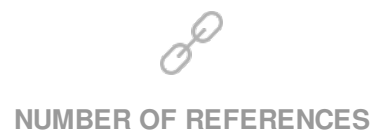

39
NUMBER OF FIGURES

4
NUMBER OF TABLES

1

(C) The author(s) 2022. This publication is an open access article. 


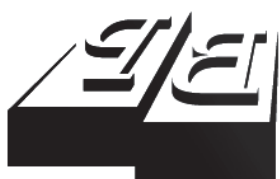

BUSINESS PERSPECTIVES

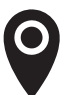

LLC "CPC "Business Perspectives" Hryhorii Skovoroda lane, 10, Sumy, 40022, Ukraine

www.businessperspectives.org

Received on: $8^{\text {th }}$ of February, 2019 Accepted on: $17^{\text {th }}$ of March, 2019

(C) Darya G. Legeza, Thomas A. Brunner, Yukilay K. Kerimova, Tatyana V. Kulish, Anastasia S. Konovalenko, 2019

Darya G. Legeza, Doctor of Economic Sciences, Associate Professor, Department of Marketing, Tavria State Agrotechnological University, Ukraine.

Thomas A. Brunner, Ph.D., Professor of Consumer Behavior, School of Agricultural, Forest and Food Sciences, Bern University of Applied Sciences, Swizerland.

Yukilay K. Kerimova, Doctor of Economic Sciences, Professor, Academician of Kazakh National Academy, Department of management and Organization of Agribusiness, Kazakh National Agrarian University, Kazakhstan.

Tatyana V. Kulish, Ph.D., Associate Professor, Department of Marketing, Tavria State Agrotechnological University, Ukraine.

Anastasia S. Konovalenko, Ph.D., Senior Lecturer, Department of Marketing, Tavria State Agrotechnological University, Ukraine.

\section{(ㄷ) (i)}

This is an Open Access article, distributed under the terms of the Creative Commons Attribution 4.0 International license, which permits unrestricted re-use, distribution, and reproduction in any medium, provided the original work is properly cited.

Darya G. Legeza (Ukraine), Thomas A. Brunner (Swizerland), Yukilay K. Kerimova (Kazakhstan), Tatyana V. Kulish (Ukraine), Anastasia S. Konovalenko (Ukraine)

\title{
A MODEL OF CONSUMER BUYING BEHAVIOR IN RELATION TO ECO-INTELLIGENT PRODUCTS IN CATERING
}

\begin{abstract}
Growing negative changes cause a deterioration in food quality, which makes people select organic and eco-intelligent food. The aim of the article is to analyze various types of customer behavior using an example of a local catering company that offers eco-intelligent food. The company's brand operates two catering stores located in different parts of an urban city. The interview of existing and potential customers was conducted within 1,000-meter radius of store locations at peak hours (7:30-10:00 am and 12:00-2:30 pm). The model of consumer behavior is centered on the main principle of deciding to buy eco-intelligent food. The data suggest that customers are looking for additional necessary services, which are vital for eco-intelligent products and expanded selection according to the store's format. Both the time of the ordering processing and the ability to order a personalized meal have the main influence on customers' decision. Large selection of eco culinary products in the stores attracts local residents to visit one of these stores at least once a week. An essential feature of a culinary store offering eco-intelligent food is high-quality prepared food. The study recommends expanding promotional programs to give consumers additional knowledge about the advantages of organic nutrition. The prevalent consumer model describes a woman under 40 years old who visits a store at least once a week for lunch and prefers a comfortable environment and a diverse selection of quality eco-food.
\end{abstract}

Keywords

JEL Classification

\section{INTRODUCTION}

Ecological factors force transformations in the volume of food production and consumption. Growing negative changes cause a deterioration in food quality, which makes people select organic and eco-intelligent food. In the last fifty years, primary and ready-made organic products have caused a growing interest among people who are concerned with their health. The lack of an eco-food supply has worried consumers in European countries since the 1980s (Fotopoulos \& Krystallis, 2002a). Researchers examining consumer consciousness in Greece have identified three criteria of consumption: health, environmental, and exploratory behavior (Fotopoulos \& Krystallis, 2002b). Mikkelsen, Kristensen, and Nielsen (2002) found that plenty of consumers from Finland and Norway have not used eco-products for the last twenty years despite the favorable ecological conditions of Nordic countries. Therefore, state agencies of various European countries have begun to take into consideration issues of health nutrition. Within the evolving discussion of ecological product consumption in Europe, the Finnish welfare service, funded by local municipalities, plays a vital role in public catering (Lehtinen, 2012). Moreover, it is essential to give chil- 
dren knowledge about the necessity of healthy consumption. Learning about catering in school helps children to recognize eco-intelligent products among others (Nölting, 2009). The education of children promotes increasing the number of intelligent customers in canteens and culinary stores.

Previous studies have shown that the main reasons for customers' dislike of eco-products were the small number of local suppliers, high prices, lack of a state support, and little variety in the eco-products offered by stores and restaurants. Difficulties in product diversification restrict the growing demand on eco-products. Recent studies on food consumption from a local caterer show that the usage of various technologies and recipes diversifies the choice of eco-products (Tikkanen, 2014). Prepared food is more convenient to address these problems and to supply higher-quality foods (Post, Shanahan, \& Jonsson, 2008). Moreover, many consumers choose local brands and recommend them to friends. It is much simpler to get information about existing manufacturers in a small community. A significant number of citizens adhere to healthy eating throughout social state support covering part of the production costs and contributing to promotional campaigns of the brands (Seyfang, 2006). Building a dialogue between caterers and customers increases the sustained volume of consumer-oriented products and develops an avenue for further financial growth (Mikkola, 2018). Any promotional campaign of a local brand supported by the government stimulates the sustainable production and consumption of healthy food in a community. In Finland, the promotional food program based on the community's economy, employment, and food usage develops local sustainable production (Risku-Norja \& Muukka, 2013; Risku-Norja \& Løes, 2016). Because local organic products are a part of sustainable consumption, caterers should develop a new management strategy that would incorporate an intelligent consumer model.

\section{LITERATURE REVIEW}

The focus of recent research has been on the topic of consumer preferences for environmentally friendly products, which include organic and eco-intelligent production. Due to the development of a significant number of small local catering businesses around the globe, entrepreneurs direct considerable efforts toward brand awareness. This makes the food market increasingly ecologically conscious (Laroche, Bergeron, \& Barbaro-Forleo, 2001). The empirical results obtained by Cheuah and Phau (2011) suggest that eco-literacy, interpersonal influence, and value orientation relate directly to ecological products. Consumers search for and buy products that will satisfy their needs because of the growing environmental pollution. Moser (2016) emphasizes that concerns for the environment make self-reported purchasing behavior more globally oriented. When consumers select "clean products", they support the growth of organic production and the effective usage of land resources. Nevertheless, production costs play a vital role in making decisions for entrepreneurs and farmers. They contribute to higher prices for eco-foods to generate a net profit that makes people reject the purchasing of eco-products. Haws et al. (2014) have found that consumption values depend on environmental, financial, and physical resources. Consumer analysis shows that a consumer makes his or her decision based on the price and health parameters of the product. Bei and Chiao (2001) include these two parameters in the consumer behavior model and the element "service quality". The problem with this approach is that most customers evaluate a catering business according to its set of services provided, such as packaging, freezing, and slicing. A modern customer wants to get a personalized order to meet his or her individual needs. It is unfair not to mention that taste plays an essential role in consumers' decision-making process. Many attempts have been made to research consumers' evaluation of taste parameters. Naspetti and Zanoli (2009) have compared consumer opinions on the taste of both organic and conventional foods. They assert that "genuine taste" is the most essential criterion to buy organic foods among others. Recent evidence shows that consumers associate a good taste of organic products with "clean" and fresh food (Hjelmar, 2011). Paul and Rana (2012) calculated that $45 \%$ of respondents are satisfied with organic food and only 3\% are "somewhat dissatisfied". Many consumers believe that eco-intelligent products are tastier than conventional 
ones. Lee, Shimizu, Kniffin, and Wansink (2013) conducted an experiment in which participants evaluated the taste of organic products presented as both organic and conventional. Unknowing members evaluated "organic" food as lower in fat and calories. Therefore, Lee and Yun (2015) emphasized that it would be efficient to offer clients taste foods at stores.

For the past several years, considerable effort has been devoted to developing a model of consumer satisfaction. A customer selects a place of purchase after he or she has evaluated several options of a product or a service (Reardon \& McCorkle, 2002). To compare the options, a customer analyzes visible criteria before and after buying (Grunert, 2002). He or she searches for both product and purchasing services. While some people prefer to look for premier products and cook at home, others like eating prepared meals in a culinary café or a restaurant. Nevertheless, food safety is a crucial factor for most consumers. The willingness to pay for value-added products directly correlates with the quality and safety of food (Grunert, 2005). The nature of product values develops further consumer's choice (Shaw et al., 2005). Several researchers have demonstrated age- and gender-based differences among consumers when they make decisions. Recent scientific results show that creating social loyalty to eco-foods should begin during school years to develop an ecologically conscious generation. School education of ecological products forms a new market segment among students. To select the necessary product, students need to evaluate products according to their experience (Newson, 2004). This may help local education authorities to promote the importance of eco-food nutrition among youth.

A consumer model is influenced by the gender identity of consumers. However, most studies to date have not considered the effect of consumers' gender on the decision-making process. Bakewell and Mitchell (2003) studied "Female Generation Y" and explained that women make their decision according to five key factors: recreation, discounts, loyalty, fashion, and time. There is a notion that women tend to socialize more and to choose products based on their mood and emotions. Kidwell et al. (2008) worked out an evalu- ation of personal consumer behavior in relation to emotions. The special analysis evaluates a selection of products based on the 18 -item scale. A woman researches a product according to her in-store and prior experiences (Granot, Greene, \& Brashear, 2010). Therefore, a female model of consumer behavior mirrors biased criteria of decision making, such as pleasure time, courtesy of store assistance, and personalized services.

In a growing digital community, a consumer makes a decision according to a group experience, based on previous customers' feedback. Users surf the Internet to find positive or negative reviews about a product, its nutritional content, and way of usage. They obtain knowledge about a product from unknown individuals. Therefore, there is an uncertain subjective perception when a consumer researches products using the Internet (Buyukozkan, 2004). However, conclusive studies on food ordering on the Internet have not been conducted, because few local catering stores use it to offer their products.

Consumers make different choices when they buy various products in various places at various times (Talluri \& Van Ryzin, 2004). An individual decision could vary when a buyer selects some products for lunch and others for dinner. The variability in purchasing time creates delays caused by long waiting lines. To equalize purchases during a day, most local stores use various brand promotional instruments. Coupons and in-store discounts help to increase loyalty to the brand and share information about brand advantages (Viswanathan, Rosa, \& Harris, 2005). Moreover, the usage of total order management creates benefits in supply chains. A combination of market opportunities and knowledge about consumers are suggested to be competitive advantages for a catering store. An evaluation of customers' loyalty basis leads to an improvement in brand attractiveness causing customers to make more purchases and recommend a store (Sirohi, McLaughlin, \& Wittink, 1998). Based on the literature review, there are various reasons for consumer decision making, such as safety, satisfaction, emotion, feedback, and time. The more a business owner knows the behavior model of a consumer, the more clearly he or she foresees market changes, which in turn, could lead to increased sales. 


\section{AIM AND TASKS}

The aim of the article is to investigate consumers' behavior using an example of a local company that offers eco-intelligent food. This type of product addresses the peculiarities of the eco-food market. Several recent studies have been done examining a theory of eco-intelligent food consumption. However, two following practical questions related to catering were left unanswered: Do consumers pay attention and select the eco-food from other types of food in a local culinary store? Who is a typical customer of a culinary store?

To answer these questions, there are following research tasks:

1) to evaluate customers' loyalty to a brand that offers eco-intelligent products among local residents;

2) to examine customers' motivation to visit a culinary store;

3) to reveal consumer preferences for eco-food;

4) to ground the necessity to expand eco-food variety;

5) to describe a consumer behavior model to develop another management strategy.

\section{METHODS}

In order to study peculiarities of various segments of consumer, two catering stores in different parts of the city have been evaluated. The original name of the brand are not revealed according to an agreement with the business owners. The method of study was an outside questionnaire to collect the necessary information. The survey method used in our study is a face-to-face interview with closed-ended questions, collected by a random sampling technique. Respondents exhibited age, gender, and social variability. The planned sample was 500 respondents from the two catering stores, but 71 forms were excluded because of incorrect and/or incomplete answers. The respondents of the interview were existing and potential consumers inside and outside the stores within a radius of one kilometer. The survey was done from 7:30-10:00 am and 12:00-2:30 pm. The questionnaire consisted of 15 answers in communicative (to establish contact with respondents), general (to reveal the main issues), research (to examine the purpose of research), and final types (to get information about respondents). The classification of questions is based on Starostina's (2012) method.

The SPSS software package was used to analyze the results of the survey and applied empirical statistical methods to group the determinant influence on consumer decision making.

\section{RESULTS AND DISCUSSION}

Both stores are in a densely populated urban area, but both are surrounded by diverse business and social infrastructure. The social forces depending of an employment status are the crucial motive of consumer behavior (Zeugner-Roth et al., 2015). From another point of view, a consumer makes his or her shopping trip according to his home or business location (Hunneman et al., 2017). Employment status and store location cause a light variety of store customers by social groups, and create ground for different strategies to satisfy customers. The results of the research show that most of the 202 respondents from store 1 are employees, state employees, and entrepreneurs because of the convenient location near business centers and state offices. The main consumers of store 2 are students and employees (mostly educators), because store 2 is within walking distance to schools and the university.

Our results show that while students often visit store 2 during peak times, they increase the number of customers standing in line. Therefore, employers prefer visiting the other store. Store 1 presents equal segments of the social groups, but employees and students dominate store 2 and account for $51 \%$ of the visitors. Each social groups of customers order various foods. While students do not spend much time there and buy hamburgers, employees prefer to order a set of menu items and eat inside. This fact requires managing an individual schedule for servicing in each store.

To evaluate the quality of services, respondents answered about the store format. Moreover, own- 


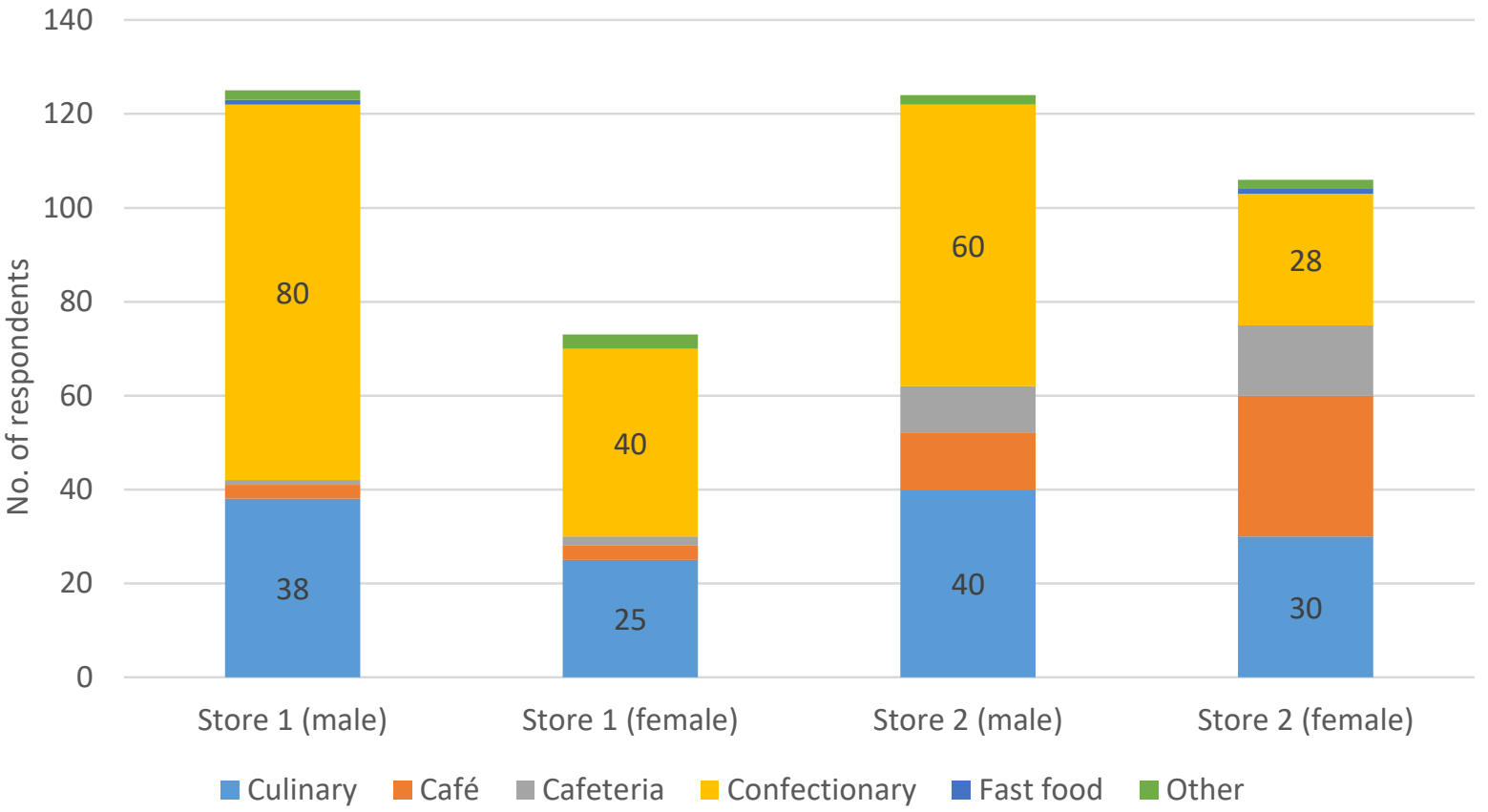

Figure 1. Distribution of the respondents by associative perceptions of a store format

ers divided stores into two sectors, such as culinary and confectionary departments. These departments offer different products and services. While the confectionary department offers only packaged cakes and does not have a cafeteria, the catering sells ready-made food that consumers can eat in store. The distribution of respondents by associative perception is presented in Figure 1.

Many men (54\%), interviewed near store 1 , considered the business a confectionary. Only $34 \%$ suggest that the store has culinary properties and $7 \%$ perceived the store as a café. There was revealed an unusual tendency: almost an equal number of women evaluated the store as a confectionary (37\%) or as a culinary store (38\%). Only $11 \%$ of the women suggested that this store operated as a café. Employees, both men and women, considered catering properties because of their personal needs. Most of the customers visit store 1 for lunch and order a personalized meal. Therefore, they pay attention to the service and the opportunity to eat inside the store. Customers from the store 1 prefer ordering a side dish to buying eco desserts. The one reason for the choice is consumers' desire to eat low-calorie foods. At this point, consumers would like to buy salads, soups, and side dishes, which are cooked in accordance with the rules of ecological technologies.
Figure 1 demonstrates that $47 \%$ of the men consider store 2 a confectionary, while $34 \%$ call it a culinary store. An in-depth analysis of the sales showed that more than $63 \%$ of the revenues come from orders of birthday cakes and chocolates. The figure indicates that $34 \%$ of the women consider the store a catering store, $27 \%$ a confectionary, and 22 a café. Men buy confections and pastries more often. Our data show that a minor segment of customers evaluates store 2 ambiguously and prefers to call it a cafeteria, because this store does not maintain modern facilities, furniture, restrooms, and other necessary elements of a catering store or café. Therefore, an equal number of men and women prefer to eat quickly inside the store. The interviewed respondents emphasize that they do not prefer to buy eco-intelligent food in a cafeteria, because they are not sure about the quality of food cooking and storage.

Our study demonstrates that respondents required additional services to buy eco-intelligent products. It is crucial for them to diversify the menu of eco-products and supply fresh foods. Respondents evaluated the main service criteria by a 5 -score scale. The results of the evaluation are illustrated in Figure 2. 


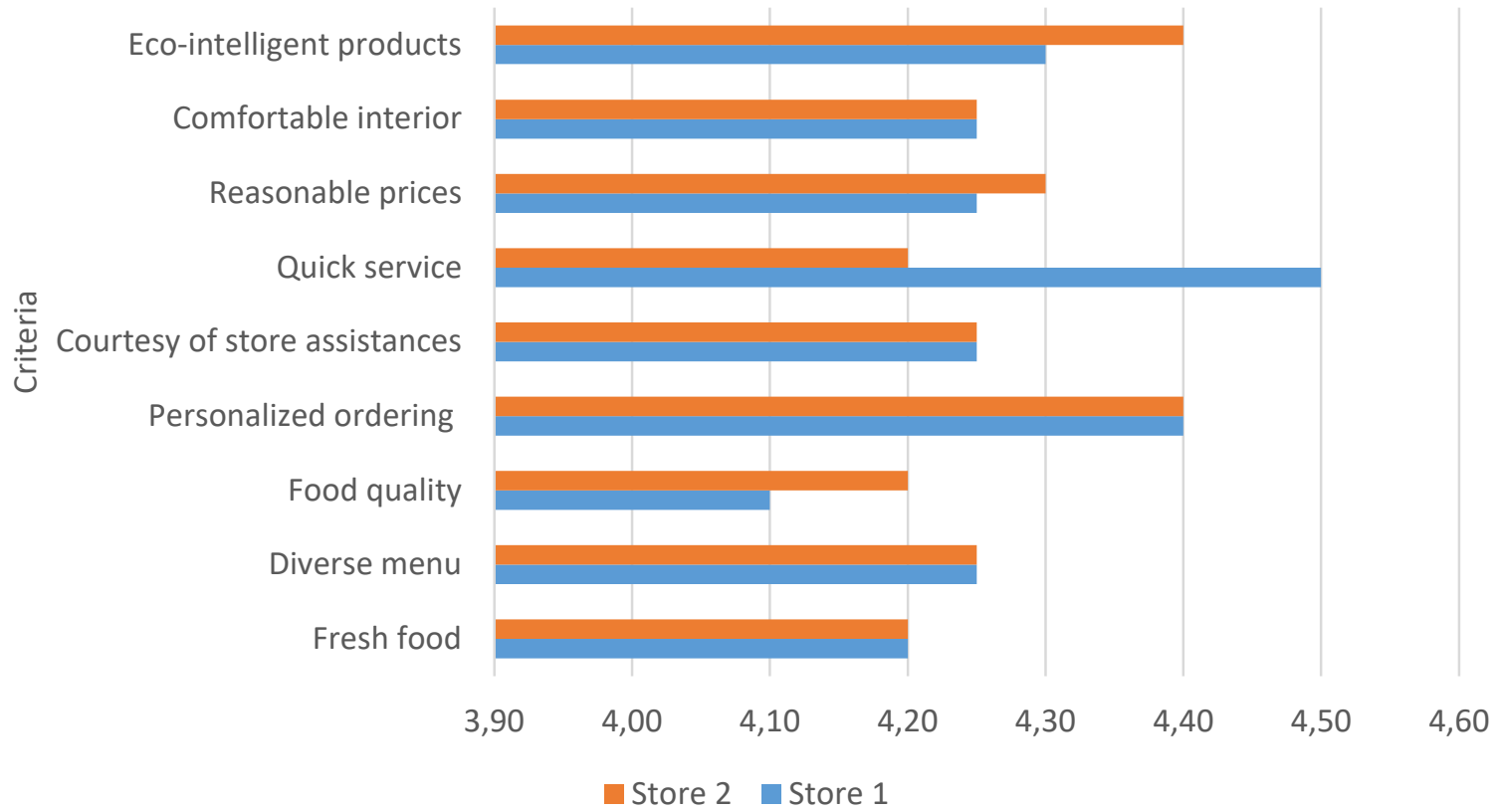

Figure 2. Service evaluation by customers: five-point scores

Each parameter has received more than 4 points. The results show that the lowest point value was assigned to food quality. The dialogue with respondents revealed their significant negative comments about the services. Some customers claimed that they were forced to refuse their order if meals were served cold during peak hours. Furthermore, customers from store 1 evaluated a proposition of eco-intelligent food as a competitive advantage of the company. The grouping of services by gender segments shows that women mostly prefer eco-intelligent food. Approximately $65 \%$ of the women select this option from other types of food. Moreover, the results show that respondents who buy eco-foods choose a diverse menu as a second option. To summarize, the main criteria to visit store 1 were existing eco-intelligent foods, reasonable prices, and personalized ordering. Respondents from store 2 preferred the quick and personalized ordering of eco-intelligent foods. Time management analysis was conducted to calculate the average waiting time in a line per person. The key argument of a long waiting time is the complicated process of ordering. It takes no less than 7 minutes for a store associate to put the meal ordered in a pack, preheat, chop, weigh, calculate the total order, collect money, give change, and put it in a store brand package bag. The ordering time lengthened during a break between the school classes when students were trying to order hamburgers and fruit croissants. Moreover, customers caused a delay when they required more time to make a choice; thus, store associates must provide more explanation and advice about meals to satisfy customers' requirements. Consumers spend approximately 30 minutes in a line, which makes them upset about the service. After the survey, the recommendations to the board of directors and managers were to improve the purchase chain management, which could speed up the ordering process. It is crucial to use a second person for assistance to share some of the duties, such as taking orders from regular customers and making containers, labels, and packages ready. Furthermore, it was suggested that they should change the job duties of the store associates to include offering fresh food to all customers.

Currently, digital marketing technologies provide various opportunities to reduce the ordering and waiting time, eliminate waiting lines in a store, and promote a brand. In digital marketing studies, Freeman et al. (2014) emphasize that the Internet applications increase ordering because of customers' feedback availability, online sales, interactive quizzes, and vouchers. Therefore, if a company offering eco-products develops a website, it can create a software platform for online ordering and picking orders up from a store. While a customer explores such a website, he or she can become more educated 


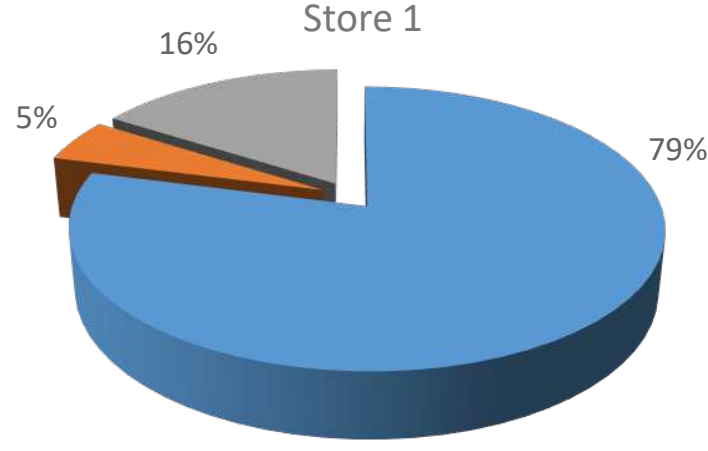

- Satisfied $\square$ Not satisfied $\square$ Possibly satisfied

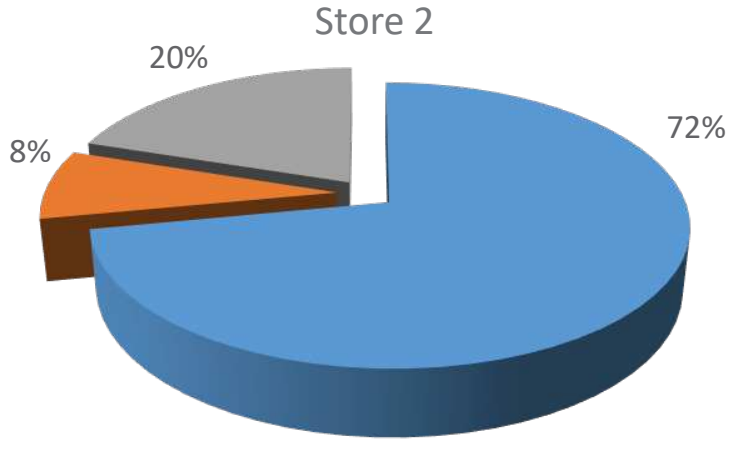

- Satisfied $\square$ Not satisfied $\square$ Possibly satisfied

Figure 3. The level of customer satisfaction with the variety of food

about the advantages of organic food consumption, fill his or her cart, and save the time often required for in-store ordering and waiting in a line.

There are more than 200 types of meals in both stores, but managers diversify a complicated list periodically depending on seasons and preferences. To address this issue, respondents were asked about their satisfaction with existing variety and their proposition of the desired changes. Figure 3 illustrates the level of customer satisfaction.

Most respondents were satisfied with the proposed meals (79\% from store 1 and $72 \%$ from store 2 ). $89 \%$ of these respondents selected eco-intelligent food from other types. This result led us to conclude that most customers meet their needs and satisfy their desire for eco-food consumption.

To modify the selection in the store, the managers should pay attention to the second group of respondents who are possibly satisfied with the set of products (16\% from store 1 and $20 \%$ from store 2 ). These people usually buy fast food and notice that it does not meet the requirements for eco-intelligent production. The consumers suggest that frozen products could not be considered an eco-intelligent food. A follow-up discussion with a product manager provided reassurance that fast food sold in the stores is an ecological product. Therefore, the company should develop a new product marketing strategy to inform local residents about food quality and the advantages of organic fast food. At the present time, students are the major consumers of fast food, but they could not evaluate the distinctiveness of eco-products. As mentioned by
Nölting (2009), a promotional campaign at schools helps to provide students with information about the advantages of eco-foods. They should know that available eco-products are not limited to only fresh products, but can be presented in a variety of prepared meals. The groups of answers introduce a "wish list" of consumers from both stores. Approximately $20 \%$ of the unsatisfied consumers from store 1 would want to buy sushi, pizza, soups, natural tea, coffee, vegetarian salads, and children's menu items. Approximately $28 \%$ of the unsatisfied consumers from store 2 order soups, fish, pizza, hot dogs, vegetarian salads, and fresh juices and pies. Rifer and Hamm (2011) have found that juvenile children preferred to consume ready-to-eat pizza more than organic products. They have proposed to expand the organic food list by adding sweets, which make the organic food market more attractive for youth. Beets et al. (2007) described a professional course in a culinary school that provided useful information about the necessity of healthy nutrition. Previous research has demonstrated that culinary courses and other training programs provide opportunities to improve student educational plan by enriching students' professional knowledge and skills with regard to eco-product utility. Therefore, a local educational authority can stimulate organic food consumption through promotional campaigns at schools. Moreover, the young generation could be a key part of society to promote information, communicate, and share knowledge with friends and relatives.

Evaluation of respondents' intention to recommend the eco-intelligent food of the brand to their friends is presented at Figure 4 . 


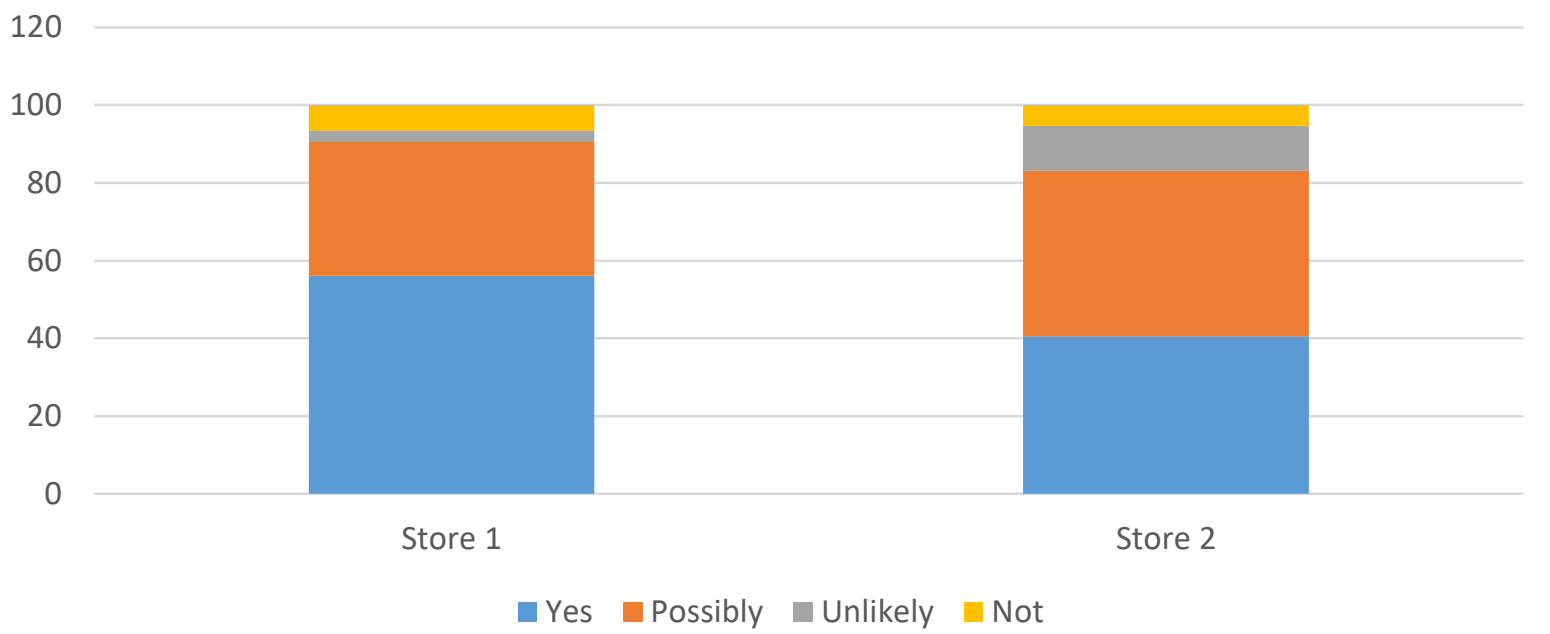

Figure 4. Distribution of the respondents by their intention to make a recommendation to friends

$56 \%$ of the respondents from the store 1 would recommend and $34 \%$ would likely recommend this brand to friends. Doubters were not sure about the food quality and were not satisfied with the existing services.

Our data show that $56 \%$ of the respondents liked their experience because of tasty food and quick ordering, $86 \%$ were satisfied with the product variety, $98 \%$ liked the store location, and $38 \%$ were regular customers. Therefore, $10 \%$ of the respondents rated the brand negatively and would not recommend store 1 to friends, because their meals were sometimes stale. Moreover, they were not satisfied with the food quality and store location. In-depth research shows that total quality control at every point in the process might help identify non-compliance with food processing standards.

The analysis of the answers related to store 2 demonstrated that $41 \%$ of the respondents would definitely recommend the store, while $43 \%$ would likely recommend it. Therefore, 140 respondents were identified as potential promoters of store 2 by various criteria. Approximately $67 \%$ of the respondents liked the store 2 because of the tasty food and quick ordering, $84 \%$ of respondents were satisfied with the food selection, $46 \%$ of the respondents liked the store location, and $28 \%$ were regular customers who visited the store daily.

School students were completely satisfied with the store location. This result suggests that the prod- uct manager should develop a promotion program of eco-intelligent food consumption targeting this age group to increase the number of ecofood consumers. $16 \%$ of the respondents evaluated store 2 negatively because of the prevalence of uncooked fresh food and lack of personalized meals. Moreover, these respondents justified their negative evaluation by the overly long waiting time of their order completion that did not fit their lunch schedule.

Table 1 summarizes the overall model of consumer buying behavior in relation to eco-intelligent food.

The model describes the prevalent male consumer buying behavior of the store 1 as a man who is younger than 30 years old (56.67\%), who is a state employee $(22.22 \%)$ or a private sector employee (24.44\%), and visits the store daily (33.33\%), once or twice a week (41.11\%) from 8:00 to 9:00 am (14.44\%) and from 11:00 am to 2:00 pm (32.22\%). Factors that are important for him are reasonable prices $(25.25 \%)$, meal quality $(25.56 \%)$, and product variety (17.78\%). In contrast, the model of the prevalent female consumer buying behavior is women in two age groups, one is from 20 to 30 years old $(46.43 \%)$ and the other is over 60 years old (15.18\%), who is an employee (25.89\%) or a pensioner (retired) (16.96\%), and visits the store daily $(22.86 \%)$ and once or twice a week (39.05\%) from 9:00 am to 12:00 pm (46.43\%). Key factors for her are the meal quality (22.32\%), food selection (21.43\%), and reasonable prices (20.54\%). 
Table 1. The model of consumer buying behavior

Source: Compiled by the authors according to consumer interviews.

\begin{tabular}{|c|c|c|c|c|c|}
\hline \multirow{2}{*}{ No. } & \multirow{2}{*}{ Criteria } & \multicolumn{2}{|c|}{ Store 1} & \multicolumn{2}{|c|}{ Store 2} \\
\hline & & Male $(44 \%)$ & Female $(56 \%)$ & Male $(45.3 \%)$ & Female $(54.7 \%)$ \\
\hline \multirow{7}{*}{1} & \multicolumn{5}{|c|}{ Age, years old } \\
\hline & Less than 20 & 26.67 & 15.18 & 15.24 & 29.51 \\
\hline & $21-30$ & 30.00 & 25.89 & 40.95 & 31.97 \\
\hline & $31-40$ & 20.00 & 20.54 & 29.52 & 19.67 \\
\hline & $41-50$ & 13.33 & 13.39 & 7.62 & 8.20 \\
\hline & $51-60$ & 4.44 & 9.82 & 4.76 & 8.20 \\
\hline & Over 60 & 5.56 & 15.18 & 1.90 & 2.46 \\
\hline \multirow{9}{*}{2} & \multicolumn{5}{|c|}{ Social status } \\
\hline & State employee & 22.22 & 10.71 & 4.76 & 3.28 \\
\hline & Employer & 4.44 & 3.57 & 12.38 & 4.92 \\
\hline & Employee & 24.44 & 25.89 & 36.19 & 24.59 \\
\hline & Entrepreneur & 13.33 & 6.25 & 12.38 & 7.38 \\
\hline & Student & 14.44 & 14.29 & 25.71 & 40.16 \\
\hline & Unemployed & 4.44 & 13.39 & 0.95 & 7.38 \\
\hline & Retired & 7.78 & 16.96 & 4.76 & 4.10 \\
\hline & Others & 8.89 & 8.93 & 2.86 & 8.20 \\
\hline \multirow{6}{*}{3} & \multicolumn{5}{|c|}{ Frequency of shopping } \\
\hline & Daily & 33.33 & 30.36 & 22.86 & 14.75 \\
\hline & One or two times per week & 41.11 & 23.21 & 39.05 & 26.23 \\
\hline & One or two times per month & 5.56 & 21.43 & 17.14 & 34.43 \\
\hline & Rarely & 16.67 & 20.54 & 16.19 & 16.39 \\
\hline & Never & 3.33 & 4.46 & 4.76 & 8.20 \\
\hline \multirow{11}{*}{4} & \multicolumn{5}{|c|}{ Time of purchase } \\
\hline & 7:00-8:00 & 8.89 & 5.36 & 4.76 & 1.64 \\
\hline & $8: 00-9: 00$ & 14.44 & 7.14 & 4.76 & 2.46 \\
\hline & $9: 00-10: 00$ & 13.33 & 13.39 & 10.48 & 10.66 \\
\hline & 10:00-11:00 & 11.11 & 15.18 & 17.14 & 9.84 \\
\hline & $11: 00-12: 00$ & 17.78 & 17.86 & 26.67 & 15.57 \\
\hline & $13: 00-14: 00$ & 14.44 & 8.04 & 17.14 & 13.11 \\
\hline & $14: 00-15: 00$ & 10.00 & 10.71 & 5.71 & 13.93 \\
\hline & $15: 00-17: 00$ & 3.33 & 12.50 & 6.67 & 11.48 \\
\hline & 17:00-18:00 & 5.56 & 6.25 & 2.86 & 16.39 \\
\hline & After 18:00 & 1.11 & 3.57 & 3.81 & 4.92 \\
\hline \multirow{7}{*}{5} & \multicolumn{5}{|c|}{ The main factors of loyalty to the brand } \\
\hline & Reasonable prices & 25.56 & 20.54 & 22.86 & 27.87 \\
\hline & Comfort & 13.33 & 17.86 & 19.05 & 12.30 \\
\hline & Assortment & 17.78 & 21.43 & 24.76 & 16.39 \\
\hline & Service & 13.33 & 16.07 & 29.52 & 24.59 \\
\hline & Quality food & 25.56 & 22.32 & 1.90 & 18.03 \\
\hline & Prestige & 4.44 & 1.79 & 1.90 & 0.82 \\
\hline
\end{tabular}

The model of the male consumer buying behavior of store 2 is a 20 - to 40 -year-old man (70.47\%), who is an employee (36.19\%) or a student $(25.71 \%)$, and visits the store daily (22.86\%), once or twice a week (39.05\%) from 10:00 am to 2:00 pm (60.95\%). It is essential for him to meet his requirements of service quality $(29.52 \%)$, food selection $(24.76 \%)$, and reasonable prices $(22.86 \%)$. The model of the female consumer buying behavior is a woman who is younger than 30 years old $(61.48 \%)$, who is an employee $(24.59 \%)$ or a student $(40.16 \%)$ and visits the store once or twice a week $(26.23 \%)$ and once or twice a month (34.43\%) from 11:00 am to 3:00 pm (60.95\%). She highly appreciates reasonable prices $(27.87 \%)$, quality service $(24.59 \%)$, and quality meals (18.03\%). 


\section{APPROBATION OF THE RESEARCH RESULTS}

The results of the study have been presented at the meeting of the board of directors and management of the company. The authors and representatives of the company have discussed the possibility of market expansion. The results suggest that most local residents were not informed about the existence of ecological food selection offered by a local company. To improve communication with the target groups of the population, management should develop a new advertising strategy involving the education and training of all store associates. Because of the young ages of the most prevalent segments of customers, it could be beneficial for store owners to build a successful social network communication program. Following a six-month campaign of research and meetings with employers, the company's sales have increased by $12 \%$.

\section{CONCLUSION}

A wide and diverse variety of prepared food and natural beverages attracts consumers of various age segments to visit a culinary store. The article presents several solutions for improving the services and the promotion of eco-intelligent food to satisfy a typical consumer of the brand. Since the compelling problem of Ukrainian catering is the waiting time in a line, product managers should pay attention to developing additional sitting places in dine-in stores, because it increases the amount of time spent inside and the size of the order. From this point of view, introducing online ordering and payment services in combination with the store pickup or dining in should make ordering easier and faster, as well as reduce lines. In particular, it is crucial to attract more female customers, especially those whose main role is homemaking, to buy eco-products and promote health consumption among their relatives. The company's management should pay more attention to the variety and expand it with natural beverages. Moreover, product managers should improve supply chain management and re-assign the job duties of store associates to speed up the ordering process. Our research has shown that the quality of products may be deteriorating during chopping, storage, or freezing. From this point of view, total quality management should maintain control at every point in the process. Finally, it would be quite useful for the company to build up a new promotional marketing conception for youth. It should educate the young generation about organic and eco-food consumption. An increase in the consumption of high-quality healthy food products by children and young people could lead to the elimination of major public health concerns and overall healthier future generations.

\section{ACKNOWLEDGEMENT}

The study is related to the Ukrainian state scientific and technical program No. 0116U002738 "Marketing strategy development of agrarian enterprises".

\section{REFERENCES}

1. Bakewell, C., \& Mitchell, V. (2003). Generation Y female consumer decision-making styles. International Journal of Retail \& Distribution Management, 31(2), 95-106. https://doi. org/10.1108/09590550310461994

2. Beets, M., Swanger, K., Wilcox, D., \& Cardinal, B. (2007). Using Hands-on Demonstrations to
Promote Cooking Behaviors with Young Adolescents: The Culinary Camp Summer Cooking Program. Journal of Nutrition Education and Behavior, 39(5), 288-289. https:// doi.org/10.1016/j.jneb.2007.05.002

3. Bei, L., \& Chiao, Y. (2001). An integrated model for the effects of perceived product, perceived service quality, and perceived price fairness on consumer satisfaction and loyalty. Journal of Consumer Satisfaction, Dissatisfaction and Complaining Behavior, 14, 125140. Retrieved from http://jcsdcb. com/index.php/JCSDCB/article/ view/110

4. Buyukozkan, G. (2004). Multicriteria decision making for emarketplace selection. Internet Re- 
search, 14(2), 139-154. https://doi. org/10.1108/10662240410530853

5. Cheah, I., \& Phau, I. (2011). Attitudes towards environmentally friendly products. Marketing Intelligence \& Planning, 29(5), 452-472. https://doi. org/10.1108/02634501111153674

6. Fotopoulos, C., \& Krystallis, A. (2002). Organic product avoidance. British Food Journal, 104(3/4/5), 233-260. https://doi. org/10.1108/00070700210425697

7. Fotopoulos, C., \& Krystallis, A. (2002). Purchasing motives and profile of the Greek organic consumer: a countrywide survey. British Food Journal, 104(9), 730-765. https://doi. org/10.1108/00070700210443110

8. Freeman, B., Kelly, B., Baur, L., Chapman, K., Chapman, S., Gill, T., \& King, L. (2014). Digital Junk: Food and Beverage Marketing on Facebook. American Journal of Public Health, 104(12) e56-e64. https://doi.org/10.2105/ AJPH.2014.302167

9. Granot, E., Greene, H., \& Brashear, T. (2010). Female consumers: Decision-making in brand-driven retail. Journal of Business Research, 63(8), 801808. https://doi.org/10.1016/j. jbusres.2010.04.006

10. Grunert, K. (2002). Current issues in the understanding of consumer food choice. Trends in Food Science \& Technology, 13(8), 275-285. https://doi.org/10.1016/s09242244(02)00137-1

11. Grunert, K. (2005). Food quality and safety: consumer perception and demand. European Review of Agricultural Economics, 32(3), 369-391. https://doi.org/10.1093/ eurrag/jbi011

12. Haws, K., Winterich, K., \& Naylor, R. (2014). Seeing the world through GREEN-tinted glasses: Green consumption values and responses to environmentally friendly products. Journal of Consumer Psychology, 24(3), 336-354. https://doi.org/10.1016/j. jcps.2013.11.002

13. Hjelmar, U. (2011). Consumers' purchase of organic food products.
A matter of convenience and reflexive practices. Appetite, 56(2), 336-344. https://doi.org/10.1016/j. appet.2010.12.019

14. Hunneman, A., Verhoef, P., \& Sloot, L. (2017). The moderating role of shopping trip type in store satisfaction formation. Journal of Business Research, 78 133-142. https://doi.org/10.1016/j. jbusres.2017.05.012

15. Kidwell, B., Hardesty, D., \& Childers, T. (2008). Consumer Emotional Intelligence: Conceptualization, Measurement, and the Prediction of Consumer Decision Making. Journal of Consumer Research, 35(1), 154-166. https:// doi.org/10.1086/524417

16. Laroche, M., Bergeron, J., \& Barbaro-Forleo, G. (2001). Targeting consumers who are willing to pay more for environmentally friendly products. Journal of Consumer Marketing, 18(6), 503-520. https://doi.org/10.1108/ eum0000000006155

17. Lee, H., \& Yun, Z. (2015). Consumers' perceptions of organic food attributes and cognitive and affective attitudes as determinants of their purchase intentions toward organic food. Food Quality and Preference, 39, 259-267. https://doi.org/10.1016/j. foodqual.2014.06.002

18. Lee, W., Shimizu, M., Kniffin, K., \& Wansink, B. (2013). You taste what you see: Do organic labels bias taste perceptions? Food Quality and Preference, 29(1), 33-39. https://doi.org/10.1016/j. foodqual.2013.01.010

19. Lehtinen, U. (2012). Sustainability and local food procurement: a case study of Finnish public catering. British Food Journal, 114(8), 1053-1071. https://doi. org/10.1108/00070701211252048

20. Mikkelsen, B., Kristensen, N., \& Nielsen, T. (2002). Organic foods in catering - the Nordic perspective. Soeborg: Danish Veterinary And Food Administration, 52. Retrieved from http://orgprints. org/2748/1/Organic_foods_in_catering_Project_report.pdf

21. Mikkola, M. (2018). Organic Eprints - Catering for sustainabil- ity: building a dialogue on organic milk. Retrieved from http://orgprints.org/16426/

22. Moser, A. (2016). Consumers' purchasing decisions regarding environmentally friendly products: An empirical analysis of German consumers. Journal of Retailing and Consumer Services, 31, 389-397. https://doi.org/10.1016/j. jretconser.2016.05.006

23. Naspetti, S., \& Zanoli, R. (2009). Organic Food Quality and Safety Perception Throughout Europe. Journal of Food Products Marketing, 15(3), 249-266. https://doi. org/10.1080/10454440902908019

24. Newson, J. (2004). Disrupting the 'Student as Consumer' Model: the New Emancipatory Project. International Relations, 18(2), 227-239. https://doi. org/10.1177/0047117804042674

25. Nölting, B. (2009). Providing organic school food for youths in Europe - Policy strategies, certification and supply chain management in Denmark, Finland, Italy and Norway. Nuremberg: International Centre for Research in Organic Food Systems (ICROFS) Retrieved from http://orgprints. org/15540/

26. Paul, J., \& Rana, J. (2012). Consumer behavior and purchase intention for organic food. Journal of Consumer Marketing, 29(6), 412-422. https://doi. org/10.1108/07363761211259223

27. Post, A., Shanahan, H., \& Jonsson, L. (2008). Food processing: barriers to, or opportunities for, organic foods in the catering sector? British Food Journal, 110(2), 160-173. https://doi. org/10.1108/00070700810849880

28. Reardon, J., \& McCorkle, D. (2002). A consumer model for channel switching behavior. International Journal of Retail \& Distribution Management, 30(4), 179-185. https://doi. org/10.1108/09590550210423654

29. Riefer, A., \& Hamm, U. (2011). Organic food consumption in families with juvenile children. British Food Journal, 113(6), 797-808. https://doi. org/10.1108/00070701111140124 
30. Risku-Norja, H., \& Løes, A. (2016). Organic food in food policy and in public catering: lessons learned from Finland. Organic Agriculture, 7(2), 111-124. https://doi. org/10.1007/s13165-016-0148-4

31. Risku-Norja, H., \& Muukka, E. (2013). Food and sustainability: local and organic food in Finnish food policy and in institutional kitchens. Acta Agriculturae Scandinavica, Section B - Soil \& Plant Science, 63(sup1), 8-18. https:// doi.org/10.1080/09064710.2013.7 71701

32. Seyfang, G. (2006). Ecological citizenship and sustainable consumption: Examining local organic food networks. Journal of Rural Studies, 22(4), 383-395. https://doi. org/10.1016/j.jrurstud.2006.01.003

33. Shaw, D., Grehan, E., Shiu, E., Hassan, L., \& Thomson, J. (2005).
An exploration of values in ethical consumer decision making. Journal of Consumer Behaviour, 4(3), 185-200. https://doi.org/10.1002/ cb. 3

34. Sirohi, N., McLaughlin, E., \& Wittink, D. (1998). A model of consumer perceptions and store loyalty intentions for a supermarket retailer. Journal of Retailing, 74(2), 223-245. https://doi.org/10.1016/ S0022-4359(99)80094-3

35. Starostina, A. O. (2012). Market research to national and international markets. Kyiv: LTD "Lazaryt-Polihraf” (in Ukrainian).

36. Talluri, K., \& van Ryzin, G. (2004). Revenue Management under a General Discrete Choice Model of Consumer Behavior. Management Science, 50(1), 15-33. https://doi. org/10.1287/mnsc.1030.0147
37. Tikkanen, I. (2014). Procurement and consumption of local and organic food in the catering of a rural town. British Food Journal, 116(3), 419-430. https://doi.org/10.1108/ bfj-05-2012-0116

38. Viswanathan, M., Rosa, J., \& Harris, J. (2005). Decision Making and Coping of Functionally Illiterate Consumers and Some Implications for Marketing Management. Journal of Marketing, 69(1), 15-31. https://doi.org/10.1509/ jmkg.69.1.15.55507

39. Zeugner-Roth, K., Žabkar, V., \& Diamantopoulos, A. (2015). Consumer Ethnocentrism, National Identity, and Consumer Cosmopolitanism as Drivers of Consumer Behavior: A Social Identity Theory Perspective. Journal of International Marketing, 23(2), 25-54. https:// doi.org/10.1509/jim.14.0038 